\title{
HABITAT MODELING FOR THE FAMILY OF RHINOCRYPTIDS IN THE RAIN FOREST IN THE SOUTH OF CHILE ${ }^{1}$
}

\author{
Roberto Moreno ${ }^{2 *}$, Juan Ramón Molina ${ }^{3}$, Miguel Ángel Herrera Machuca ${ }^{3}$, Noemi Salvador Soler ${ }^{4}$ and \\ Ricardo Zamora ${ }^{3}$
}

\footnotetext{
${ }^{1}$ Received on 26.05.2016 accepted for publication on 12.12.2017.

${ }^{2}$ Universidad Autónoma de Chile, Instituto de Estudios del Hábitat, Temuco-Chile. E-mail: <roberto.moreno@uautonoma.cl>.

${ }^{3}$ Universidad de Córdoba, Departamento de Ingeniería Forestal, Córdoba- Espanha. E-mail: <092momaj@uco.es $>,<$ mherrera@uco.es $>$ and <ig1zadir@uco.es>.

${ }^{4}$ Universidad Autónoma de Chile, Centro de Investigación Multidisciplinario de La Araucanía, Temuco- Chile. E-mail: <noemi.salvador@uautonoma.cl>.

*Corresponding author.
}

\begin{abstract}
Fragmentation and degradation of forest habitats affects (the susceptibility of several species is high) highly sensitive species, provoking a serious decrease in biodiversity. To deal with this problem it is necessary to consider the conservation level of bioindicator species and the development of a sustainable forest management of the natural resources. Within this framework, the current study poses the statistical binomial logit modeling to identify the potential habitat of endemic birds (Rhinocryptids) in rain forests in the south of Chile, biodiversity "hostpot" worldwide. The research allowed to identify a potential area of habitat of 14619 hectares with high probability presence of the studied birds. This area presented certain habitat constraints both topographic and vegetation factors. The studied birds showed a high selection of habitats associated to mixed forests of Nothofagus species, sites with high stratification and understory presence. The low quantity of Rhinocryptidae family species was associated to exclusive forests of Araucaria araucana, which exist at higher altitudes. The model of potential habitat of bioindicator birdlife (avifauna) within a system of geographic information it is presented as an efficient tool of information among the degree of alteration of ecosystems and for decision-makings in native forest management.
\end{abstract}

Keywords: Forest management; Conservation (preservation); Biodiversity

\section{MODELANDO DE HABITAT PARA FAMÍLIA DE RINOCRÍPTIDOS EM FLORESTA TEMPERADA NO SUL DO CHILE: APLICAÇÃO A CORDILHEIRA DE NAHUELBUTA}

\begin{abstract}
RESUMO - A fragmentação e degradação de habitats florestais afeta espécies altamente sensíveis, causando um sério declínio na biodiversidade. Para resolver este problema é necessário considerar o nível de conservação de espécies bioindicadoras e desenvolver o manejo florestal sustentável dos recursos naturais. Neste contexto, o presente estudo sugere o uso de modelagem estatística Logit binomial para identificação de potencial habitat de aves endêmicas (Rinocríptidos) em florestas temperadas do sul do Chile, "hotspot" da biodiversidade global. A pesquisa identificou um potencial de 14,619 hectares de habitat com alta probabilidade de presença das aves estudadas. Esta área apresenta certas condições particulares de habitat, tanto topográficas como de vegetação. As aves estudadas apresentaram alta selecção de habitat associado com florestas mistas de espécies de Nothofagus, locais com alta estratificação de vegetação arbustiva e presença de sotoboque. A baixa presença de espécies Rinocríptidos foi associada com florestas puras Araucaria araucana, presentes em altitudes mais elevadas. O modelo de habitat potencial bioindicador para as aves, integrado a um sistema de informação geográfica, é mostrado como uma ferramenta eficiente de informação sobre o grau de alteração dos ecossistemas e para tomada de decisão na gestão de florestas nativas.
\end{abstract}

Palavras-Chave: Gestão de florestas; Conservação; Biodiversidade. 


\section{INTRODUCTION}

At global, regional and local levels a huge concern is declared because of the loss of biodiversity (Hunter and Brehm, 2003; Miranda et al., 2015) and homogenization of landscape (Devictor et al., 2008). The existence of wider diversity of species, genetic diversity and the ecosystem structural complexity allow a bigger and better adaptation of ecosystems to changes (Smith et al., 2000; Martín et al., 2014). As opposed, ecosystems of fewer biodiversity are more fragile and susceptible to disturbances (Graham et al., 2006), facts that could alter its integrity and stability more easily (Chapin et al., 2000).

Chile has a great variety of forest ecosystems, within the native forests; rain forests in the south of Chile are remarkable. These forests are highly fragmented because of anthropic and natural pressures (Molina et al., 2016). Forest fragments are considered one of the main shelters of the biodiversity of the planet (Holanda et al., 2010), that is why their care should be a priority for our governments.

Habitats degradation of bioindicator species could provoke a decrease in biodiversity (Castellón and Sieving, 2006; Fahrig, 2003), by which the diagnosis and later decision making is of great importance for sustainable management of the resources and conservation of biodiversity (Lopez-Alfaro et al., 2012; Singh and Kushwaha, 2011).

The present work aims at modeling of the potential habitat of four species from the family Rhinocryptidae, based on an analysis of the ecophysiographical variables of importance in the presence of the selected species (Mezquida, 2004; Moreno et al., 2010; Naoki et al., 2006).

\section{MATERIALAND METHODS}

\subsection{Study area}

The study area is located in Nahuelbuta Mountain Range, which corresponds to the section of the mountain range of the coast of Chile located to the South of the Bío-Bío river $\left(37^{\circ} 11^{\prime} \mathrm{S}\right)$ and to the North of Imperial river $\left(38^{\circ} 45^{\prime} \mathrm{S}\right)$ (fig 1). The selected area corresponded to 156732.24 ha, both public and private ownership, highlighting the presence of the "Nahuelbuta National Park".

\subsection{Generation of ecophysiographical information for the construction of the model}

The model is based on topographical and ecological variables. Topographic variables, altitude, slope and exposure were used for evaluating these parameters using a digital spatial resolution $25 \times 25$ m elevation model (Rodriguez y Silva et al., 2010).
Source: own elaboration

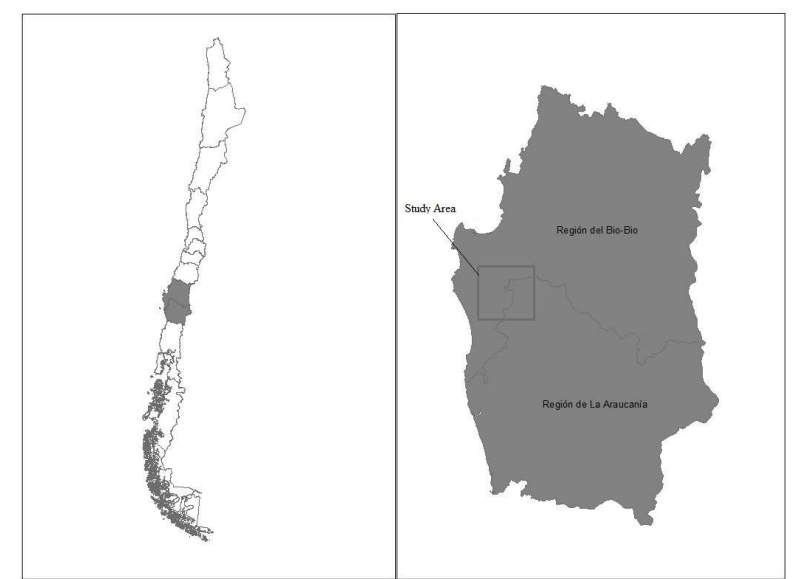

Figure 1 - Map of ubication of the study area.

Figura 1-Mapa de localização da área de estudo.

The altitudinal categorization was based on hight above the sea level (Luebert and Pliscoff, 2004; Pliscoff and Luebert, 2006) defining three intervals or categories (<895 m.a.s.1, $895-1175$ m.a.s.l and $>1175$ m.a.s.l). The slope was categorized in five categories $(<15 \%, 15-30 \%, 30-45 \%, 45-60 \%$ and $>60 \%$ ) in function of the types of vegetation management prepared by native forest law, finally the exposure was categorized into three categories (shade, partial-shade, and sunny).

In relation to environmental variables, the cartographic work allowed us to identify eight types of land use: urban use, meadow, scrubland, plantation and forest of Araucaria araucana, mixed forest of $A$. araucana and Nothofagus spp., Nothofagus spp. forest and Nothofagus spp. forests with tolerant species. Characteristics of the four forest types allowed to evaluate differences in three strata canopy referred to: Dominant (more than $75 \%$ of the sunburnt foliage), codominant (between $50-75 \%$ of the sunburnt foliage), intermediate (between $25-50 \%$ of the sunburnt foliage) and delated (less than $25 \%$ sunburnt tree tops)

\subsection{Inventory of birds}

The inventory of birds was carried out using the method of listening stations (Blondel et al., 1981; GonzalezOreja et al., 2010). Fifty circular listening stations of $20 \mathrm{~m}$ radius were set up within the forests of the study area, separated at $250 \mathrm{~m}$. To eliminate the edge effect, gathering the data less than $30 \mathrm{~m}$ from the axis of the roads is bypassed (Bibby et al., 1992; Moreno et al., 2010). 
The inventory recorded the presence of birds in each listening station according to their listening or watching (Filloy and Bellocq, 2007). The study included four species from the family of Rhynocryptidae: Pteroptochos tarnii (Hued-Hued), Scelorchilus rubecula (Chucao), Scytalopus magellanicus (Churrín) and Eugralla paradoxa (Churrín de la Mocha), designated as bioindicators of forests in balance and high biodiversity (Moreno, et al., 2011; Soto-Mora and Urrutia, 2010) by their specificity to the habitat.

\subsection{Statistical analysis}

The statistical analysis was based on the binomial logistic modeling, whose result is interpreted as the probability (p) for the prediction of the high diversity of birds, according to a range of independent variables (predictors).

The selection of this model is justified by obtaining, not only the probability of an event, but also the influence or relative importance of the variables in the model (Graf et al., 2005; Jalkanen and Mattila, 2000; Martin et al., 2014). In addition to being more robust than other statistical techniques when normal conditions are not met (Martí Ballester, 2012; Quintero et al., 2017). The result will be the probability that an area or potential habitat is associated with the presence of a high diversity of Rhinocryptids.

\section{RESULTS}

The statistical model employed a differential of the qualitative categories of exposure $\left(\alpha_{E 1}, \alpha_{E 2}, \alpha_{E 3}\right)$ and the type of vegetation $\left(\alpha v_{1}, \alpha v_{2}, \alpha v_{3}\right)$, and analysis direct from the quantitative categories of altitude $\alpha_{\mathrm{A} 1}$ and slope $\alpha_{\mathrm{P} 1}$ (Table 1).

There were not Rhinocryptids listening or bird watching in pure forests of $A$. araucana, so this category of vegetation was deleted, generating the following

Table 1 - Model and coefficients.

Tabla 1 - Modelo e coeficientes.

\begin{tabular}{lcr}
\hline Model \\
\hline$y_{(1)}=\frac{1}{\left(1+E x p^{(-x)}\right)}$ \\
$x=\left(\alpha_{0}+\alpha_{V 1} V_{(1)}+\alpha_{V 2} V_{(2)}+\alpha_{V 3} V_{(3)}+\alpha_{P} P-\alpha_{E 1} E_{(1)}+\alpha_{E 2} E_{(2)}+\alpha_{E 3} E_{(3)}-\alpha_{A} A\right)$ \\
\hline Coefficients & & \\
\hline \multicolumn{4}{c}{$-21,254$} & 0,847 & 20,71 \\
43,066 & 0,099 & 0,187 \\
0,374 & $-20,826$ & $-0,265$ \\
Source: own elaboration & &
\end{tabular}

encoding of variables for the model: mixed forest of A. araucana and Nothofagus spp. $\left(\alpha \mathrm{V}_{1}\right)$, Nothofagus spp. forest, $\left(\alpha_{\mathrm{B}}\right)$ and Nothofagus spp. forest with species tolerant $\left(\alpha V_{3}\right)$ and its ratios (B) and the exponential coefficients (Exp (B)) for each variables considered in the model (Table 2).

The goodness of fit of the models is collaborated by Hosmer -Lemeshow test. The high significance of the test 0,911 according to the analysis performed, indicating a good fit of the model, which can be interpreted as the absence of significant differences between the observed and predicted by the model values. This test was supplemented by the coefficient of determination of Nagelkerke. The value of $\chi 2$ was 2.698 and $\mathrm{R}^{2}$ of Nagelkerke reached the value of 0.42 , i.e. which explains $42 \%$ of the variance of the ecophysiographical variable.

The application of the model and extrapolation using the GIS obtained a map of potential Rhinocryptids microhabitat for the zone of study (Fig.2). We used five qualitative categories of potential habitat for the visual interpretation of the results: Very Low $(<20 \%)$, Low (20-40\%), Moderate (40-60\%), High (60-80\%) and Very High ( $>80 \%)$.

\section{DISCUSSIONS}

This study confirms the importance of ecophysiographical variables in the selection of species of fauna, mainly those bioindicators of the quality of ecosystems, such as the species of the family of the rhinocryptids (Amico et al., 2008; Moreno et al., 2011). Such importance is increasing in highly vulnerable ecosystems, such as the temperate forests of Chile,

Table 2 - Variables and coefficients (B, Exp (B)) model. Tabela 2 - Variáveis e coeficientes (B, Exp (B)) modelo.

\begin{tabular}{lcc}
\hline Variables & $\mathrm{B}$ & $\operatorname{Exp}(\mathrm{B})$ \\
\hline Exposure & & \\
Exposure(1) & 20,826 & $1,108 \mathrm{E} 9$ \\
Exposure (2) & 20,710 & $9,870 \mathrm{E} 8$ \\
Exposure (3) &, 187 & 1,205 \\
Slope &, 099 & 1,104 \\
Altitude &,- 265 &, 767 \\
Vegetation & & \\
Vegetation (1) & 43,066 & $5,050 \mathrm{E} 18$ \\
Vegetation (2) &, 374 & 1,453 \\
Vegetation (3) &, 847 & 2,332 \\
Constant & $-21,254$ &, 000 \\
Source: own elaboration & &
\end{tabular}

Revista Árvore. 2017;41(6):e410612 


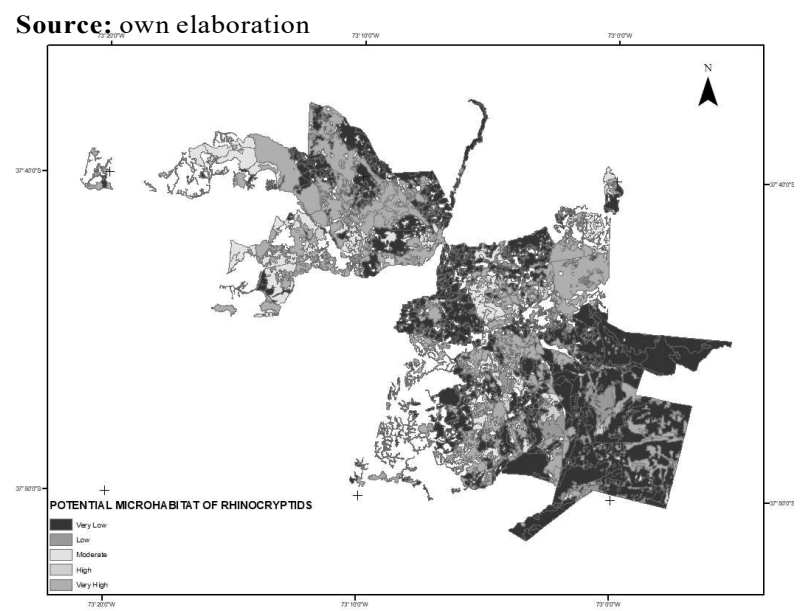

Figure 2 - Mapa of potential microhábitat of rhinocryptids. Figura 2 - Mapa de microhabitat potencial preditivos rinocríptidos.

due to the fragmentation of the native forest and high anthropogenic pressure (Castellón and Sieving, 2007; Echeverria et al., 2006).

The set of abiotic variables and vegetation allowed a good prediction of potential habitat, based on the selection/ use of the same habitat by studied birds, confirming the utility of the logit model recommended for studies with small size samples as those associated with predictions of habitat (Martin et al., 2014; Jalkanen and Mattila, 2000). The greatest biodiversity arose in sun exposure and partial-shade areas, mostly the latter, like other studies (Avendaño et al., 2015). Above 1,175 $\mathrm{m}$ altitude, the presence of the species studied considerably decreased, in direct relation with the presence of pure forests of A. araucana. Similarly, a preference of the species was obtained by areas of low and moderate slope $(<45 \%)$, that could be associated to limited mobility of birds occupants of the forest floor (Moreno et al., 2011; Krabbe and Schulenberg, 2017).

It has not been found an abundance of the species selected in forest of Nothofagus with tolerant species, possibly due to their high fraction of coverage canopy and understory cover. Birds selected as potential habitat forests of A. araucana and Nothofagus spp., usually multi-structuraded with some coverage of the understory (Amico et al., 2008; Hermes et al. 2017). less populated the sites with a high presence of shade-tolerant species. This fact is justified from the point of view of the need

Revista Árvore. 2017;41(6):e410612 for a forest habitat, with a plant structure that provides food, shelter from predators and security nest (SotoMora and Urrutia, 2010) but not excessively closed preventing mobility (Krabbe and Schulenberg, 2017).

Similarly, the number of strata of vegetation was associated with the presence of the species selected (Amico et al., 2008). The greatest biodiversity associated with the presence of three strata of vegetation (dominant, intermediate and suppressed) or four strata (dominant, codominant, intermediate, and suppressed), which ratifies the vulnerability of these birds to the degradation and fragmentation of the mixed forests (A. araucana with Nothofagus spp.). This study involved the absence or low presence of birds studied in mono-stratification forests or with low coverage of the canopy, which comes to corroborate the fragility of these species before natural and/or anthropogenic perturbations, involving the loss of the multi layered structure forest.

The exponential model estimated from the information generated by the listening stations, although it explains only $42 \%$ of the variability in the range of variance of the study, presents an acceptable value, close to other similar models (Graf et al., 2005; Ludwig et al., 2009). The low values of the statistical analysis in this matter may respond to the great variability of the natural environment and the need for a sample of larger size for the modelling of ecological parameters (Anderson et al., 2003; Ludwig et al., 2009).

The employment of the $\mathrm{R}^{2}$, as test of goodness of fit the model should be analyzed with caution, since it may not be construed as a determination coefficient of a linear regression, given the pseudo-R-squared (López-Roldán and Fachelli, 2015), which prevents the model reaches the value 1 . The logistic model has been built based on predictor variables categorized, that determines which value of $\mathrm{R}^{2}$ is only indicative, unlike of in continuous variables (Bewick et al., 2005).

Extrapolation of the information to the area of study using GIS identified $57.53 \%$ of the study area as "Very high potential" ( $14530.17 \mathrm{ha}$ ) and $68.5 \%$ as potential suitable for selected species (table 3 ).

From the studied area, there is a $26.73 \%$ which presents associated characteristics to "very low potential of habitat", usually associated with pure $A$. araucana forests located above 1175 m.a.s.l and mainly with monostratification and with low coverage in the understory due to extreme weather conditions. These results support 
Table 3 - Potential microhabitat of the birds under study, probability of presence and surface category.

Tabela 3 -Microhabitat potencial das aves em estudo, a probabilidade de presença e de superfície.

\begin{tabular}{cccc}
\hline $\begin{array}{l}\text { Potential } \\
\text { microhabitat }\end{array}$ & $\begin{array}{c}\text { Probability } \\
\text { of presence (\%) }\end{array}$ & $\begin{array}{c}\text { Surface } \\
\text { (ha) }\end{array}$ & $\begin{array}{c}\text { Surface } \\
(\%)\end{array}$ \\
\hline Very low & $0-20$ & 6751.07 & 26.73 \\
Low & $20-40$ & 1189.33 & 4.71 \\
Half & $40-60$ & 2698.45 & 10.68 \\
high & $60-80$ & 88.42 & 0.35 \\
Very high & $80-100$ & 14530.17 & 57.53 \\
\hline$\quad$ Total & & 25257.44 & 100 \\
\hline Source:
\end{tabular}

Source: own elaboration

the relevance and preference of the family of the Rhinocryptids by Nothofagus forest (Moreno et al. 2014; Reid et al., 2004).

In Figure 2 you can see the distribution by categorization of potential habitat. It is possible to infer that there is the opportunity to generate biological corridors or sectors of monitoring space of bioindicator species (Sánchez-Azofeifa et al., 2002; Rouget et al., 2006), which contribute to a more sustainable management of forest ecosystems and its biodiversity.

\section{CONCLUSIONS}

It is possible to establish a modeling of the potential habitat of four species from the Rhinocryptidae family, based on ecophysiographical variables: specifically, in the case of birds studied, they present a greater habitat selection in multi layered structure forest and multispecies, understory media coverage with sunny and partial- shade exposure.

The potential habitat of birds generated bioindicator model, delivers relevant information as a tool for the design of action measures for the conservation of biodiversity and, consequently, sustainable forest management, both for the selection of cutting methods as for the promotion of the conservation of the diversity of species present and the maintenance of ranges of coverage of the understory, situations that would enhance the sustainability of forest ecosystems of high ecological value.

In the context of the sustainability of forests temperate South of Chile, high ecological and landscape value, a study of potential habitat should be incorporated together variables of a topographical nature and vegetation. Such importance is enhanced when it comes to the conservation of wildlife species, highly fragile to degradation and fragmentation of its potential ecosystems, such as birds of the Rhinocryptids group. The availability of mapping of biodiversity and fragility of these species may allow the design of biological corridors or buffer of the loss of biodiversity and mitigation measures.

\section{REFERENCIAS}

Amico GC, Garcia D, Rodriguez-Cabal MA. Estructura espacial y uso del microhábitat dependiente de la escala de "tapaculos" (Rhinocryptidae) endémicos en un bosque templado de Sudamérica austral. Ecol Austral. 2008;18:169-80.

Anderson R, Lew D, Peterson A. Evaluating predictive models of species' distributions: criteria for selecting optimal models. Ecol Modell. 2003;162(3):211-32. http://dx.doi.org/10.1016/S03043800(02)00349-6.

Avendaño JE, Cuervo AM, López-O JP, GutiérrezPinto N, Cortés-Diago A, Cadena CD. A new species of tapaculo (Rhinocryptidae: Scytalopus) from the Serranía de Perijá of Colombia and Venezuela. Auk. 2015;132(2):450-66. http:// dx.doi.org/10.1642/AUK-14-166.1.

Bewick V, Cheek L, Ball J. Statistics review 14: logistic regression. Crit Care. 2005;9(1):112-8. http://dx.doi.org/10.1186/cc3045. PMid:15693993.

Bibby CJ, Burgess ND, Hill DA. Bird census techniques. London: Academic Press; 1992. 257 p.

Blondel J, Ferry C, Frochot B. Point counts with unlimited distance. Stud Avian Biol. 1981;6:414-20.

Castellón TD, Sieving KE. Landscape history, fragmentation, and patch occupancy: models for a forest bird with limited dispersal. Ecol Appl. 2006;16(6):2223-34. http://dx.doi.org/10.1890/10510761(2006)016[2223:LHFAPO]2.0.CO;2. PMid:17205900.

Castellón TD, Sieving KE. Patch network criteria for dispersal-limited endemic birds of South American temperate rain forest. Ecol Appl. 2007;17(8):2152-63. http://dx.doi.org/10.1890/060945.1. PMid:18213959. 
Chapin FS 3rd, Zavaleta ES, Eviner VT, Naylor RL, Vitousek PM, Reynolds HL, et al. Consequences of changing biodiversity. Nature. 2000;405(6783):234-42. http://dx.doi.org/10.1038/ 35012241 . PMid:10821284.

Devictor V, Julliard R, Clavel J, Jiguet F, Lee A, Couvet D. Functional biotic homogenization of bird communities in disturbed landscapes. Glob Ecol Biogeogr. 2008;17(2):252-61. http://dx.doi.org/ 10.1111/j.1466-8238.2007.00364.x.

Echeverria C, Coomes D, Salas J, Rey-Benayas JM, Lara A, Newton A. Rapid deforestation and fragmentation of Chilean Temperate Forests. Biol Conserv. 2006;130(4):481-94. http://dx.doi.org/ 10.1016/j.biocon.2006.01.017.

Fahrig L. Effects of habitat fragmentation on biodiversity. Annu Rev Ecol Syst. 2003;34(1):487515. http://dx.doi.org/10.1146/ annurev.ecolsys.34.011802.132419.

Filloy J, Bellocq MI. Patterns of bird abundance along the agricultural gradient of the Pampean region. Agric Ecosyst Environ. 2007;120(2-4):2918. http://dx.doi.org/10.1016/j.agee.2006.09.013.

González-Oreja JA, de la Fuente-Díaz-Ordaz AA, Hernández-Santín L, Buzo-Franco D, BonacheRegidor C. Evaluación de estimadores no paramétricos de la riqueza de especies. un ejemplo con aves en áreas verdes de la ciudad de puebla, méxico. Anim Biodivers Conserv. 2010;33(1):31-45.

Graf R, Bollmann K, Suter W, Bugmann H. The importance of spatial scale in habitat models: capercaillie in the Swiss Alps. Landsc Ecol. 2005;20(6):703-17. http://dx.doi.org/10.1007/s10980005-0063-7.

Graham N. A J., Wilson SK, Jennings S, Polunin NVC, Bijoux JP, Robinson J. Dynamic fragility of oceanic coral reef ecosystems. Proc Natl Acad Sci USA. 2006;103(22):8425-9. http://dx.doi.org/ 10.1073/pnas.0600693103. PMid:16709673.

Hermes C, Jansen J, Schaefer H. Habitat requirements and population estimate of the endangered Ecuadorian Tapaculo Scytalopus robbinsi. Bird Conserv Int. 2017. In press. http:// dx.doi.org/10.1017/S095927091600054X.
Holanda AC, Feliciano ALP, Marangon LC, Santos MS, Melo CLSMS, Pessoa MML. Estrutura de espécies arbóreas sob efeito de borda em um fragmento de floresta estacional semidecidual em Pernambuco. Rev Arvore. 2010;34(1):103-14. http://dx.doi.org/10.1590/S010067622010000100012 .

Hunter LM, Brehm J. Qualitative insight into public knowledge of, and concern with, biodiversity. Hum Ecol. 2003;31(2):309-20. http:// dx.doi.org/10.1023/A:1023988914865.

Jalkanen A, Mattila U. Logistic regression models for wind and snow damage in northern Finland based on the National Forest Inventory data. For Ecol Manage. 2000;135(1-3):315-30. http:// dx.doi.org/10.1016/S0378-1127(00)00289-9.

Krabbe NK, Schulenberg TS. Chucao Tapaculo (Scelorchilus rubecula). In: del Hoyo J, Elliott A, Sargatal J, Christie DA, Juana E, editors. Handbook of the birds of the world alive. Barcelona: Lynx Edicions; 2017.

López-Alfaro C, Estades CF, Aldridge DK, Gill RMA. Individual-based modeling as a decision tool for the conservation of the endangered huemul deer (Hippocamelus bisulcus) in southern Chile. Ecol Modell. 2012;244:104-16. http:// dx.doi.org/10.1016/j.ecolmodel.2012.06.032.

López-Roldán P, Fachelli S. Análisis de regresión logística: metodología de la investigación social cuantitativa. Bellaterra: Dipòsit Digital de Documents, Universitat Autònoma de Barcelona; 2015.

Ludwig T, Storch I, Graf RF. Historic landscape change and habitat loss: the case of black grouse in Lower Saxony, Germany. Landsc Ecol. 2009;24(4):533-46. http://dx.doi.org/10.1007/s10980009-9330-3.

Luebert F, Pliscoff P. Clasificación de pisos de vegetación y análisis de representatividad ecológica de áreas propuestas para la protección en la ecorregión Valdiviana. Valdivia: WWF Chile; 2004. (Serie de Publicaciones WWF; no. 2).

Martí Ballester CP. Análisis de los factores que influyen en el desempeño académico de los alumnos de contabilidad financiera a través de

Revista Árvore. 2017;41(6):e410612 
modelos de elección binaria. Rev Bras Gest Neg. 2012;14(45):379-99.

Martín MA, Mattioni C, Lusini I, Molina JR, Cherubini M, Drake F, et al. New insights into the genetic structure of Araucaria araucana forests based on molecular and historic evidences. Tree Genet Genomes. 2014;10(4):839-51. http:// dx.doi.org/10.1007/s11295-014-0725-1.

Mezquida ET. Patrones de orientación de los nidos de passeriformes en una zona árida del centro-oeste de Argentina. Ornitol Neotrop. 2004;15(2):145-54.

Miranda A, Altamirano A, Cayuela L, Pincheira F, Lara A. Different times, same story: native forest loss and landscape homogenization in three physiographical areas of south-central of Chile. Appl Geogr. 2015;60:20-8. http://dx.doi.org/ 10.1016/j.apgeog.2015.02.016.

Molina JR, Martín Á, Drake F, Martín LM, Herrera MÁ. Fragmentation of Araucaria araucana forests in Chile: quantification and correlation with structural variables. IForest. 2016;9(2):244-52. http://dx.doi.org/10.3832/ ifor1399-008.

Moreno RA, Zamora R, Herrera MA. Habitat selection of endemic birds in temperate forests in a biodiversity " Hotspot. For Syst. 2014;23(2):21624. http://dx.doi.org/10.5424/fs/2014232-03700.

Moreno RA, Zamora R, Molina J, Herrera M, Vásquez A. Propuesta de plan de gestión forestal utilizando criterios de conservación de fauna de alto valor ecológico en bosques templados de Sudamérica (Región de Araucanía, Chile). Revista Montes. 2010;103:16-21.

Moreno RA, Zamora R, Molina JR, Vasquez A, Herrera MÁ. Predictive modeling of microhabitats for endemic birds in South Chilean temperate forests using Maximum entropy (Maxent). Ecol Inform. 2011;6(6):364-70. http://dx.doi.org/10.1016/ j.ecoinf.2011.07.003.

Naoki K, Gómez MI, López RP, Meneses RI, Vargas J. Comparación de modelos de distribución de especies para predecir la distribución potencial de vida silvestre en Bolivia. Ecol Boliv. 2006;41(1):65-78.
Pliscoff P, Luebert F. Ecosistemas terrestres. In: Comision Nacional del Medio Ambiente. Biodiversidad de Chile: patrimonio y desafíos. Santiago: CONAMA; 2006. p. 74-87.

Quintero C, Freire E, García JO, Salazar J, Delgado L. El índice de gobierno corporativo y su relación con el desempeño financiero: un estudio de empresas que emitieron en la bolsa de valores de Guayaquil en el 2013. Revista Espacios. 2017;38(28):12.

Reid S, Diaz I, Armesto J, Willson M. Importance of native bamboo for understory birds in Chilean temperate forests. Auk. 2004;121(2):515-25. http:// dx.doi.org/10.1642/00048038(2004)121[0515:IONBFU]2.0.CO;2.

Rodríguez Y, Silva F, Alvear GJ, Soto M, Molina JR, Cerda C, et al. Aplicación y adaptación del modelo SEVEIF para la evaluación socioeconómica del impacto de los incendios forestales en la Provincia de Valparaíso, Chile. Córdoba: Agencia Española de Cooperación Internacional para el Desarrollo (AECID), Programa de Cooperación Interuniversitaria e Investigación Científica entre España e Iberoamérica; 2010.51 p.

Rouget M, Cowling RM, Lombard AT, Knight AT, Kerley GIH. Designing large-scale conservation corridors for pattern and process. Conserv Biol. 2006;20(2):549-61. http://dx.doi.org/10.1111/j.15231739.2006.00297.x. PMid:16903115.

Sánchez-Azofeifa G, Daily GC, Pfaff ASP, Busch C. Integrity and isolation of Costa Rica's national parks and biological reserves: Examining the dynamics of land-cover change. Biol Conserv. 2002;109(1):123-35. http://dx.doi.org/10.1016/S00063207(02)00145-3.

Singh A, Kushwaha SPS. Refining logistic regression models for wildlife habitat suitability modeling: a case study with muntjak and goral in the Central Himalayas, India. Ecol Modell. 2011;222(8):1354-66. http://dx.doi.org/10.1016/ j.ecolmodel.2011.02.012.

Smith B, Burton I, Klein RJT, Wandel J. An anatomy of adaptation to climate change and variability. Clim Change. 2000;45(1):223-51. http:// dx.doi.org/10.1023/A:1005661622966.

Soto-Mora Y, Urrutia J. Evaluación del estado de conservación de cuatro especies de aves de la familia Rhynocryptidae en un área silvestre protegida en el sur de Chile. Acta Zool Mex. 2010;26(2):401-14. http://dx.doi.org/10.21829/ azm.2010.262714. 